\section{'Esquimalt' Red Raspberry}

\author{
Chaim Kempler, ${ }^{1}$ Hugh A. Daubeny ${ }^{2}$ and Brian Harding ${ }^{3}$
}

Agriculture and Agri-Food Canada, Pacific Agri-Food Research Centre, P.O.

Box 1000, Agassiz, B.C., Canada V0M 1 AO

\section{Chad E. Finn ${ }^{4}$}

\section{U.S. Department of Agriculture-Agriculture Research Service, Horticultural Crops Research Laboratory, Northwest Center for Small Fruit Research, Corvallis, OR 97330}

Additional index words. Rubus idaeus, fruit breeding, fruit quality, fresh market, yield, disease resistance

'Esquimalt' (Fig. 1) is a new floricane-fruiting red raspberry (Rubus idaeus L.) cultivar from the breeding program at the Pacific AgriFood Research Centre (PARC) of Agriculture and Agri-Food Canada (AAFC), Agassiz, B.C. 'Esquimalt' produces high yields of large, firm fruit that ripen late, and is well suited to fresh market sales. It is resistant to the common strain of the North American raspberry aphid, Amphorophora agathonica Hottes, a vector of the raspberry mosaic virus (RMV) complex. 'Esquimalt' is a B.C. First Nations word, which translates as "a place gradually shoaling", and is a city and a harbour on the southern tip of Vancouver Island. The choice of name follows the tradition of naming PARC berry cultivars with local First Nations words.

\section{Origin}

'Esquimalt', which was tested as BC 89-289, was selected by H.A. Daubeny from a 1989 cross of 'Comox' $\times$ 'Glen Ample'. 'Comox', released from PARC program in 1987, was chosen as a parent because of its high yield and good fruit quality (Daubeny, 1987). 'Glen Ample', released from the Scottish Crop Research Institute in 1994, was chosen as a parent because of its high yield and adaptability to the fresh market (Daubeny, 1997; Raffle and Allen, 2001). The origin of 'Esquimalt' demonstrates the value of collaboration and exchange between breeding programs using germplasm of diverse origins.

\section{Performance and Description}

Performance data for 'Esquimalt' and several other Pacific Northwest cultivars, including

Received for publication 17 May 2005. Accepted for publication 8 July 2005 . This research was partially funded by the Raspberry Industry Development Council,Lower Mainland Horticultural Improvement Association, and the Washington Red Raspberry Commission. We gratefully acknowledge the assistance of L. Frey, M. Gross, and M. Bodnar, of Pacific AgriFood Research Centre (PARC); M. Sweeney, British Columbia Ministry of Agriculture Food and Fisheries; T. Baumann, Univ. College of the Fraser Valley; P. Moore, Wash. State University, Puyallup; R. Martin, USDA Corvallis, Ore. PARC. contribution.

${ }^{1}$ Research scientist.

${ }^{2}$ Research scientist (retired)

${ }^{3}$ Research technician.

${ }^{4}$ Research geneticist. adjusted according to the yield for each harvest. the widely planted 'Meeker' and 'Tulameen', were obtained from three replicated plantings set in 1993, 1997, and 2000 at PARC's substation in Abbotsford, B.C. (Table 1). The 1993 and 2000 planting were evaluated for 3 years, starting in 1995 and 2002 respectively, and the 1997 planting was evaluated for 5 years starting in 1999. Each planting was arranged in a randomized complete-block design in which each cultivar was represented by three 3-plant replications with $0.9 \mathrm{~m}$ between plants and $3 \mathrm{~m}$ between rows. Yield, fruit weight, fruit firmness, dates of harvest and postharvest fruit rot (caused primarily by Botrytis cinerea Pers. ex. Fr.) were measured each season from 1995 to 2004. Soluble solids concentration (SSC), firmness, titratable acidity and postharvest fruit rot tests were carried out according to Barritt et al. (1980) and Daubeny and Pepin (1974). Fruit were harvested from 9 to 14 times a season, at 3- to 7-d intervals, depending on the length of a cultivar's harvest period and environmental conditions. The average fruit weight for the season is a weighted mean, calculated from the weight of a randomly selected 50 fruit subsample from each plot on each harvest and The fruit ripening season was characterized by

Fig. 1. 'Esquimalt' red raspberry.

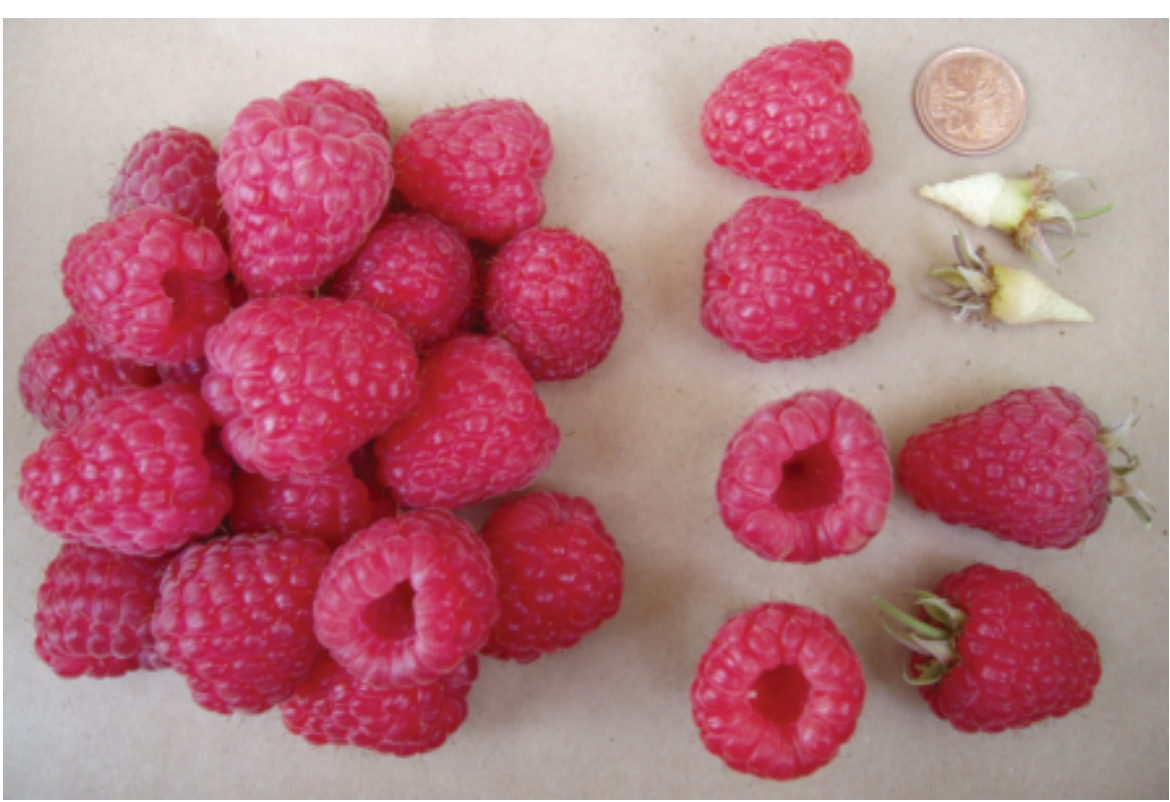

the dates at which $5 \%, 50 \%$, and $95 \%$ were reached(Table 1). Fruit firmness was measured as the force required to close the opening of the fruit with a push-pull spring gauge (Hunter Spring Mechanical Force Gauge Series L; Ametek, Hatfield, Pa.) and was calculated on subsamples of ten randomly selected fruit, three to five times each harvest season. Fruit samples were frozen until determination of $\mathrm{pH}$ and titratable acidity (as a percentage of citric acid) on a thawed subsample. 'Esquimalt' was also evaluated in Washington (planted in 1999, WSU, Puyallup), Oregon (planted in 2000, Oregon State University-North Willamette Research and Extension Center), and in Oxford, U.K. (planted in 2003, ADAS Horticulture). 'Esquimalt' was also evaluated in British Columbia, Washington, and Oregon grower fields.

For all the variables, the interaction of cultivar $\times$ planting year and cultivar $\times$ harvest year was nonsignificant, hence the data presented are means of all harvest years for each cultivar (Tables 1 and 2). 'Esquimalt' yield and fruit size were significantly higher than the other Pacific Northwest cultivars in this comparison (Table 1), which included 'Qualicum' and 'Tulameen', each of which is recognized for high yield and large fruit size (Daubeny and Kempler, 1995, 2003). The harvest season of 'Esquimalt' is late, starting a few days later than 'Meeker', 'Tulameen', and 'Qualicum', and almost 2 weeks later than 'Malahat', which is recognized for its earliness (Kempler and Daubeny, 2000) (Table 1). The harvest duration is relatively long, similar to that of 'Malahat' and 'Tulameen', and longer than that of 'Meeker' and 'Qualicum'.

'Esquimalt' fruit is meaty, round to short conic in shape (Fig. 1) and has large drupelets that can bleed when bruised; fruit color is medium to light red and the fruit appears shiny. Overall fruit appearance is attractive and excellent. The 'Esquimalt' soluble solids concentration was significantly lower then the tested cultivars and fruit firmness was the highest of all the tested cultivars, although 
Table 1. Yield and harvest season for 'Esquimalt' and other Pacific Northwest red raspberry cultivars. ${ }^{2}$

\begin{tabular}{|c|c|c|c|c|c|c|c|}
\hline \multirow[b]{2}{*}{ Cultivar } & \multirow{2}{*}{$\begin{array}{c}\text { Yield } \\
\text { (kg/hill) }\end{array}$} & \multirow{2}{*}{$\begin{array}{c}\text { Fruit } \\
\mathrm{wt}^{\mathrm{x}}(\mathrm{g})\end{array}$} & \multirow{2}{*}{$\begin{array}{c}\text { Fruit } \\
\operatorname{rot}(\%)\end{array}$} & \multicolumn{3}{|c|}{ Harvest season $^{\mathrm{y}}$} & \multirow{2}{*}{$\begin{array}{l}\text { Harvest } \\
\text { duration } \\
\text { (days) }\end{array}$} \\
\hline & & & & $5 \%$ & $50 \%$ & $95 \%$ & \\
\hline Esquimalt & $5.52 \mathrm{a}^{\mathrm{w}}$ & $4.9 \mathrm{a}$ & $3.4 \mathrm{c}$ & 8 July a & 24 July a & 8 Aug. a & $33 \mathrm{a}$ \\
\hline Malahat & $3.57 \mathrm{c}$ & $4.1 \mathrm{c}$ & $1.9 \mathrm{~d}$ & 28 June d & 11 July e & 1 Aug. c & $34 \mathrm{a}$ \\
\hline Meeker & $3.46 \mathrm{c}$ & $2.9 \mathrm{~d}$ & $1.6 \mathrm{~d}$ & 6 July b & 20 July b & 4 Aug. b & $30 \mathrm{~b}$ \\
\hline Qualicum & $4.56 \mathrm{~b}$ & $4.4 \mathrm{~b}$ & $5.4 \mathrm{a}$ & 4 July c & 16 July d & 31 July c & $28 \mathrm{c}$ \\
\hline Tulameen & $4.38 \mathrm{~b}$ & $4.4 \mathrm{~b}$ & $4.5 \mathrm{~b}$ & 6 July b & 19 July c & 9 Aug. a & $34 \mathrm{a}$ \\
\hline
\end{tabular}

${ }^{z}$ Yield, fruit weight and harvest dates are means from four plantings made in 1993, 1999, and 2000, harvested for 3 years each.

${ }^{y}$ Harvest season $=$ the date at which $5 \%, 50 \%$, and $95 \%$ of the yield were harvested.

${ }^{x}$ Fruit weight was based on mean of 50 fruit/harvest.

wMean separations within columns by Duncan's multiple range test, $P=0.05$.

firmness was only significantly higher than that of 'Meeker' (Table 2). Percent postharvest fruit rot of 'Esquimalt' was similar to that of 'Meeker' and 'Qualicum', lower than percent postharvest fruit rot of 'Tulameen', and higher than percent postharvest fruit rot of 'Malahat', all of which are recognized for having lower levels of susceptibility to postharvest fruit rot than some other cultivars (Daubeny and Kempler, 1995; Kempler and Daubeny, 2000). The $\mathrm{pH}$ and the titratable acidity of 'Esquimalt' are very similar to those of 'Qualicum' and the other tested cultivars. This similarity suggests that, like 'Tulameen' and 'Qualicum', 'Esquimalt' is acceptable for the fresh market. When fruit is harvested before reaching the proper ripening stage, a few drupelets often break. This may create problems in harvesting fruit that is not completely ripe for long distance shipping.

'Esquimalt' flowers are self fertile, and the percentage of drupelets set under field conditions appears to be similar to that of 'Qualicum', 'Malahat', and 'Meeker', each of which is recognized for a high percentage of set (Daubeny, 1971; Daubeny and Kempler, 1995; Kempler and Daubeny, 2000).

In unreplicated trials planted in 1999 at Washington State University, Puyallup, on a fragariae Hickman var. rubi Wilcox \& Duncan (syns. P. erythroseptica Pethyp., P. megasperma Drechs.), 'Esquimalt' produced a low yield. The fruit was small and the production season was late. The poor performance was attributed to 'Esquimalt's' susceptibility to site that is heavily infected with Phytophthora

Phytophthora root rot (P. Moore, personal communication). In genotype trials at the Oregon State University-North Willamette Research and Extension Center in Aurora, Ore., 'Esquimalt' yield was significantly higher than 'Meeker'and the other B.C. cultivars in the trial (Table 3). The mean fruit size of 'Esquimalt' was significantly higher than the other cultivars including of that of 'Qualicum' and 'Tulameen', two cultivars that are grown mainly for the fresh market. 'Esquimalt' harvest season started 1 week later than any cultivar. The last harvest date of 'Esquimalt' was later than that of 'Meeker', but was similar to that of 'Qualicum' and 'Tulameen'(Table 3). In unreplicated trials planted in 2002 in Forest Hill, Oxford, U.K., the 'Esquimalt' harvest duration lasted over 7 weeks. This duration was longer than that of 'Glen Ample' and 'Tulameen', the main fresh market cultivars that are grown in Europe, as well as the recently released cultivar 'Octavia' (J. Allen, unpublished data). The fruit size of Esquimalt was the smallest of the three cultivars throughout the harvest period. In this trial, 'Esquimalt' fruit was attractive, easy to detach from the receptacle and had an excellent, sweet flavour.

'Esquimalt' plants are very vigorous, with an upright growing habit and thick canes that are spineless. 'Esquimalt' floricanes are greyish brown with little cracking and they produce long and strong laterals. 'Esquimalt' produces more primocanes than 'Qualicum', 'Meeker', and 'Tulameen'(data not presented). The laterals are strongly attached and display

Table 2. Fruit traits of 'Esquimalt' and other Pacific Northwest red raspberry cultivars. ${ }^{z}$

\begin{tabular}{|c|c|c|c|c|c|}
\hline Cultivar & $\begin{array}{l}\text { Soluble } \\
\text { solids } \\
(\%)\end{array}$ & $\begin{array}{c}\text { Firmness } \\
\text { (N) }\end{array}$ & $\begin{array}{l}\text { Botrytis-incited } \\
\text { fruit rot after } \\
48 \mathrm{~h}(\%)\end{array}$ & $\mathrm{pH}$ & $\begin{array}{c}\text { Titratable } \\
\text { acidity } \\
\text { (\% citric acid) }\end{array}$ \\
\hline Esquimalt & $9.7 \mathrm{~b}$ & $2.45 \mathrm{a}$ & $30.5 \mathrm{~b}$ & 2.87 & $1.12 \mathrm{ab}$ \\
\hline Malahat & $10.7 \mathrm{a}$ & $2.11 \mathrm{a}$ & $21.6 \mathrm{c}$ & 2.93 & $0.97 \mathrm{~b}$ \\
\hline Meeker & $10.6 \mathrm{a}$ & $1.52 \mathrm{~b}$ & $32.5 \mathrm{~b}$ & 2.86 & $0.95 \mathrm{~b}$ \\
\hline Qualicum & $11.1 \mathrm{a}$ & $2.27 \mathrm{a}$ & $29.3 \mathrm{~b}$ & 2.87 & $1.14 \mathrm{ab}$ \\
\hline Tulameen & $11.1 \mathrm{a}$ & $2.16 \mathrm{a}$ & $37.5 \mathrm{a}$ & 2.82 & $1.20 \mathrm{a}$ \\
\hline
\end{tabular}

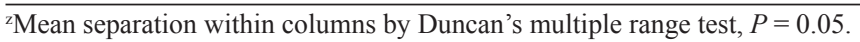

Table 3. Yield, berry size and ripening season for summer fruiting raspberry genotypes at OSU-NWREC planted in 2000 and harvested in 2002-04.

\begin{tabular}{lccccc}
\hline & Yield & Berry & \multicolumn{3}{c}{ Harvest season } \\
\cline { 3 - 5 } Genotype & $\left(\mathrm{kg} \cdot \mathrm{m}^{-2}\right)$ & size $(\mathrm{g})$ & $5 \%$ & $50 \%$ & $95 \%$ \\
\hline Esquimalt & $15.9 \mathrm{a}^{\mathrm{z}}$ & $5.6 \mathrm{a}$ & 1 July & 15 July & 2 Aug. \\
Meeker & $12.5 \mathrm{~b}$ & $3.6 \mathrm{~d}$ & 30 June & 12 July & 25 July \\
Qualicum & $11.6 \mathrm{bc}$ & $5.0 \mathrm{~b}$ & 26 June & 9 July & 25 July \\
Cowichan & $10.5 \mathrm{bcd}$ & $4.4 \mathrm{c}$ & 26 June & 9 July & 25 July \\
Tulameen & $9.5 \mathrm{~cd}$ & $4.8 \mathrm{~b}$ & 28 June & 14 July & 1 Aug. \\
Willamette & $8.5 \mathrm{~d}$ & $3.7 \mathrm{~d}$ & 21 June & 4 July & 18 July \\
\hline
\end{tabular}

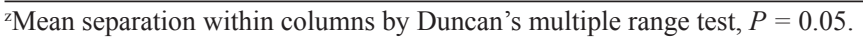

fruit well to pickers. The fruit are well spaced on the laterals.

'Esquimalt' has been characterized by sequence repeat SSR marker analysis for 3 markers; the patterns obtained were group 2, 5 , and 1 for the first, second, and third markers respectively (Graham et al., 2002).

\section{Disease and Pest Reaction}

'Esquimalt' was selected in greenhouse screening trails for resistance conferred by the gene $\mathrm{Ag}_{1}$ to the common biotype of $A$. agathonica Hottes, the North American aphid vector of the raspberry mosaic virus (RMV) complex. Aphid colonization has been noted on plants in PARC trials. We assume that this is a resistantbreaking biotype of the aphid, which has been found on other cultivars with $A g_{1}$ gene (Kempler and Daubeny, 2000). 'Esquimalt' has been indexed yearly (1993-2004) for RMV using the double-stranded RNA technique (Kurppa and Martin, 1986) and for raspberry bushy dwarf virus (RBDV) using the enzyme-linked immunosorbent assay technique (ELISA). 'Esquimalt' has tested negative to RMV since the genotype was selected. RMV pressure in the Pacific Northwest is low, however, and so that does not mean 'Esquimalt' is resistant to RMV (Martin, 2002). 'Esquimalt' tested positive to RBDV for the first time in 1998, when infected plants did not show yellow symptoms but produced crumbly fruit unsuited for the fresh market.

In growers' trials throughout the Pacific Northwest, 'Esquimalt' showed less susceptibility to root rot caused by Phytophthora fragariae than 'Malahat'.

In the Pacific Northwest, 'Esquimalt' has a similar level of susceptibility to spur blight [Didymella applanata (Niessl)Sacc.] as 'Qualicum', 'Tulameen', and 'Malahat', and lower susceptibility than 'Meeker' and 'Willamette'. 'Esquimalt' has low susceptibility to cane Botrytis (B. cinerea) and to Anthracnose (Elsinoe veneta Burkh.) (data not presented).

\section{Adaptability and Uses}

The fruit of 'Esquimalt' is very large and firm with an excellent fresh flavor, all of which make it well suited for the fresh market. Because of its fruit size, upright growing habit, spineless canes and fruit that is well displayed to pickers, it is suited for hand picking and particularly for u-pick operations. Although it is firm and has good post harvest qualities, it is 
prone to bruising and can bleed because of its large drupelets and thin skin. This makes it most suited to supplying the local and short distance fresh market. Because 'Esquimalt' ripens later than most Pacific Northwest cultivars, it could be used to extend the fresh market season.

\section{Availability}

Certified 'Esquimalt' plants are being propagated under royalty agreements with propagators in the Pacific Northwest. For licensing information, contact Okanagan Plant Improvement Company (PICO), P.O. Box 6000, Summerland, BC, V0H 1Z0, Canada, e-mail PICO@agr.gc.ca.

\section{Literature Cited}

Barritt, B.H., L.C. Torre, H.S. Pepin, and H.A. Daubeny. 1980. Fruit firmness measurements in red raspberry. HortScience 15:38-39.

Daubeny, H.A. 1971. Self-fertility in red raspberry cultivars and selections. J. Amer. Soc. Hort. Sci. 96:588-591.

Daubeny, H.A. 1987. Chilliwack and Comox red raspberries. HortScience 22:1343-1345.

Daubeny, H.A. 1997. Raspberry, p. 635-662. In: The Brooks and Olmo register of fruit and nut varieties. 3rd ed. ASHS, Alex., Va.

Daubeny, H.A. and C. Kempler. 1995. 'Qualicum' red raspberry. HortScience 30:1470-1472.

Daubeny, H.A. and C. Kempler. 2003. 'Tulameen'red raspberry. J. Amer. Pomol. Soc. 57(2):42-44.

Daubeny, H.A. and H.S. Pepin. 1974. Variations among red raspberry cultivars and selections in susceptibility to the fruit rot causal organisms, Botrytis cinerea and Rhizopus spp. Can. J. Plant Sci. 54:511-516.

Graham, J., K. Smith, M. Woodhead, and J. Russell. 2002. Development and use of simple sequence repeat SSR markers in Rubus species. Molecular Ecol. Notes 2:250-252.

Kempler, C. and H. A. Daubeny. 2000. Malahat red raspberry. HortScience 35:783-785.

Kurppa, A. and R.R. Martin. 1986. Use of doublestranded RNA for identification of virus diseases of Rubus species. Acta Hort. 186:51-62.

Martin, R.R. 2002. Virus diseases of Rubus and strategies for their control. Acta Hort. 585:265-270

Raffle, S. and J. Allen. 2001. Profiting from protection. Grower (15 Feb.):14-16. 